\title{
Choosing a Copyright Assessment Method in Evaluating a Fiduciary Guarantee Object in Indonesia
}

\author{
Taufik. H. Simatupang ${ }^{1, *}$ Nizar Apriansyah ${ }^{1}$ Trisapto Wahyudi Agung Nugroho ${ }^{1}$ \\ Edward James Sinaga ${ }^{1}$ Antonio Rajoli Ginting ${ }^{1}$ Adis Nurhayati ${ }^{1}$ \\ ${ }^{I}$ The Agency of Research and Development of Law and Human Rights of the Ministry of Law and Human Rights \\ of The Republic of Indonesia \\ *Corresponding author. Email TaufikHSimatupang73@gmail.com
}

\begin{abstract}
The theorem states that developed countries whose natural resources are unarguable again. Nowadays, the development of a nation is determined by the mastery of science and technology that can generate products and processes that are valuable, economically. Countries in the world are competing to provide facilities to encourage the creative process for inventors to create works in the fields of science, art, literature, and industry. One of easiness is the regulation. Indonesia currently makes a significant breakthrough in the Copyright Act that gives a chance for creators and copyright holders to apply for a certificate of copyright as an object of fiduciary guarantee. However, until today there are not banks or financial institutions that will provide loans with a copyright guarantee. In carrying out the mandate on the Copyright Act Number 28/2014 article 16 paragraph (3) that states copyright certificates can be objects of fiduciary assurance, it is necessary to find a method to estimate or assess the economic value of the copyright. Otherwise, the bank will not give credit. And finally, this provision is worthless as results the state's will to stimulate the creators' creativity is not achieved. This research aims to examine the methods that fit and are implemented in Indonesia. This study uses a normative research method with a statutory approach that uses secondary data as the main data in the form of primary, secondary, and tertiary legal materials to formulate a method of determining the value of a copyright certificate. This research is normative legal research that uses secondary data as the main data, in the form of primary, secondary, and tertiary law materials. The results show that there are three known approaches to estimate the economic value of copyright. The first is the cost approach method, which is an assessment method based on the expenses in developing or creating copyright work or developing a similar product. A second method is a market approach, namely the valuation method by comparing recent sales, transfers, and transactions involving the same assets in the same market. Then, the third is revenue approach methods, namely the approach to determining economic value based on a revenue time to come. Indonesia can choose the market value approach method. The market value approach will succeed in case that the government ensures that there are technical implementing regulations governing the use of copyright as collateral for the debt, mandatory registration of copyright in a public register of works, and an independent copyright assessment agency.
\end{abstract}

Keywords: copyright, fiduciary guarantee, method of assessment.

\section{INTRODUCTION}

Copyright is a part of intellectual property that has the broadest scope because it includes science, art, and literature, including computer programs. The development of the creative economy is one of the mainstays of Indonesia and other countries in the world. The fast advancement of information and communication technology necessitates a renewal of the Copyright Act, considering that copyright is the most major basis of the national creative economy. The Copyright Act, which has implemented 
elements of protection and development of the creative economy, is expected to contribute to the copyright sector and related rights for the state economy.

it requires adequate protection of intellectual property, especially creations born from cultural diversity and scientific wealth.[1] The fast advancement of video and audio recording, telecommunication, and digital information technology in the last few decades requires firm protection for creators and related rights owners but still pays attention to the interests of the wider community. If the demands of property rights protection are seriously taken care of by the government, with serving a good regulatory system, then the state economy will be increased, and the credibility of the nation remains secured in the international world.[1]

Developed countries which have limited natural resources take steps to boost the economy by mastering science and technology, namely generating products and services that have economic value. Today, countries in the world are competing to provide facilities to encourage the creative process of inventors to create works in the fields of science, art, literature, and industry. One of the conveniences is through regulations that provide space and legal certainty for inventors to continue to innovate.

In fulfilment of the community's need for legal certainty, the Indonesian government has issued Law Number 28 of 2014 concerning Copyright. This law is to adjust the development of information and communication technology which has a strategic role in copyright.

Article 16 paragraph (3) states that "A Copyright may be used as an object of fiduciary collateral". In the next paragraph, it is mentioned that the provision regarding Copyright as the object of fiduciary collateral is implemented under the provisions of laws and regulations. This regulation certainly provides legal certainty for copyright holders to guarantee their works. With this regulation, synchronization occurs between the Fiduciary Guarantee Law and the Copyright Law.

Based on the records of the National Collective Management Institution (LMKN), music royalties for creators' rights and related rights have increased significantly since 2016. In 2016, LMKN managed to collect royalties of 22 billion Rupiahs. Furthermore, in 2017, there was an increase in music royalty revenue which reached 36 billion Rupiahs.
Indonesia has a diversity of ethnic groups, cultures, and religions as well as abundant wealth in the fields of science, art, and literature including its development. As a national potential,

Then at the end of 2018, the collection of music royalties reached 66 billion Rupiahs.[2]

The potential royalty from the copyrighted work above shows that a copyrighted work can be estimated at its economic value. This research tries to provide a choice of methods that can be used by financial institutions to interpret the value of copyright as an object of fiduciary guarantee.

\section{RESEARCH METHOD}

This research is normative juridical research, where normative legal is related to the type of research so that it used a statutory approach. This approach examines the laws governing the Fiduciary Guarantee on a work/creation. The statutory approach will also look at how the method of assessing copyright as a fiduciary guarantee can be regulated in applicable laws and regulations.

Library material is the primary material for research which is generally referred to as primary legal material in this research which consists of Law Number 28 of 2014 concerning Copyright and Law Number 42 of 1999 concerning Fiduciary. Whereas, the secondary legal materials in this research are books, journals, legal articles, documents related to copyright as a Fiduciary Guarantee.

\section{FINDINGS AND DISCUSSION}

\subsection{Economic Potential and Copyright Royalties}

The development of the digital world and technology fosters various kinds of creativity and innovation. Creativity and innovation are one of the intellectual property, which is copyright. Copyrights can be in the forms of music, films, books, and so on. This work gives rise to moral rights and economic rights in it. Authors can earn economic benefits or royalties for their copyright that are used by others.

Copyright can be used as an object of fiduciary guarantee as stipulated in Article 16 Paragraph (3) of Law Number 28 of 2014 concerning Copyright. This provision can be one of the motivations for the creator to continue to develop his creation. However, there is no financial institution that is willing to accept a copyright certificate as an object of 
fiduciary guarantee; it is because there is no method to estimate the economic value of the copyright.

The PRISINDO Collective Management Institution (Performer's Rights Society of Indonesia) revealed that there were five singers with the highest royalties in Indonesia in 2019, namely Via Vallen, Anji, Judika, Iwan Fals, and Cita Citata. Also, there were band groups that also got the highest royalties in 2019, namely Armada, NOAH, Ungu, Seventeen, and Naff.[3] The Karya Cipta Indonesia Collective Management Institution (LMK KCI) distributes royalties to all songwriters who registered as authorizers, totalling more than 3,000 people throughout Indonesia. The number of royalties given by KCI in 2019 reached Rp. 5.3 billion. This number was much bigger than the previous year that was only Rp. 4.5 billion.[4]

Books as copyright can also generate royalties. On average, book writers receive a royalty of $10 \%$ of the selling price. In some publishers, the numbers may be smaller or larger. Some writers who are well known can get a royalty of $12-15 \%$ of the selling price of the book. It depends on the initial agreement between the author and publisher.[5] A film as a copyrighted work must also be clear about the parties related to the ownership rights of the intellectual property. The screenwriter (creator) with the producer (copyright user) in the negotiation to determine the royalty fee must first perform a professional contract so that if a dispute occurs, it can be resolved well. In films, there is much intellectual property that must be protected, namely songs, music, scripts, scripts, taglines, logos, and even film titles. As a producer, they must understand, recognize, record, compensate and secure the intellectual property in the film.[6]

Copyright covers the fields of science, art, and literature. The objects of copyright are generally both immaterial and intangible such as musical works, films, novels, dances, games, computer programs, architectural designs, graphic designs, etc. For copyright objects like this, it can only be bound by a Fiduciary Guarantee which includes two types of collateral binding, namely:

1) Copyright Certificate (as Basic Collateral), and

2) License Agreement or Franchise Agreement that can generate royalties (as Additional Collateral).[7]

For copyright objects that are tangible (material) and objects (tangible) such as paintings or sculptures can be used as objects of Fiduciary security without having to be accompanied by additional collateral. Paintings or sculptures can also be tied with a pledge if the object of the collateral is kept by the creditor. Copyrights for paintings or sculptures are generally transferred through a broken sale, making the guarantee process much easier. The Fiduciary Guarantee of Copyright must be made based on a notary deed and registered with the Fiduciary Registration Office under the Ministry of Law and Human Rights. Because the Copyright Certificate is held by the creditor, if the debtor (Copyright Holder) wants to exercise his exclusive rights (such as making a License/Franchise Agreement), the debtor must first obtain permission from the creditor.[7]

\section{Chart of Copyright Guarantee Through Fiduciary Guarantee Scheme.[7]}

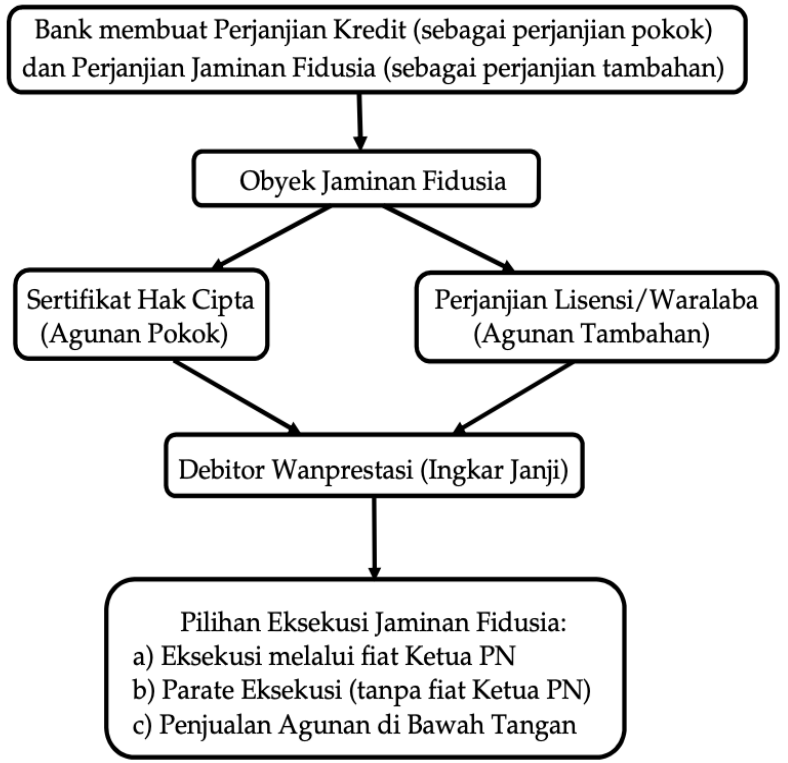

The chart above describes a fiduciary guarantee scheme with a copyright certificate as the object, starting with the credit agreement as to the main agreement, and then the fiduciary guarantee agreement as an additional agreement. The object of the fiduciary guarantee is in the form of a copyright certificate and a license agreement to see the royalties generated. If in the future the debtor defaults, the creditor can execute the collateral. A fiduciary guarantee certificate has the same executorial power as a court decision that has permanent legal force. If the debtor is in default, the Fiduciary Recipient has the right to sell objects that are the object of the Fiduciary Guarantee on his authority without asking the fiat of the Head of the District Court. The sale of the objects can be made through public auctions or underhand.[7]

Objects that can be used as fiduciary security, of course, must have a measurable value as collateral for the repayment of debts. In this case, copyright as 
an object of fiduciary guarantee is difficult to measure the value of the right, because what is guaranteed is the intellectual right of the work. It requires a third party as an appropriate guarantee appraisal agency for the copyright to become a guarantee.

It must be acknowledged that the issue of copyright as a fiduciary guarantee is not an easy matter. First, it must be understood that the construction of copyright in Indonesia is divided into economic rights and moral rights. Copyright can be a fiduciary guarantee to the extent of its economic rights. Second, this transferable economic right also makes the Copyright Holder not always the Creator. "For example, books become commercial when they are sold. When a writer gives a publishing license, can the debtor by the writer or publisher?". It becomes more complex when it comes to copyright in music. Music creators, producers, performing artists, and composers each have economic rights to the same form of work. "Even though there is only one item, namely a recorded work,"[9]

In practice, to date, no single financial institution has implemented this provision. It is related to the application of the prudential banking principle, where banks must obtain certainty of refunds that have been lent to artists.

Practitioners of financial institutions in Indonesia still encounter several obstacles in their implementation. These obstacles are related to matters:

1) The economic value of a copyright,

2) Ownership of copyright (Indonesia adhering to a declarative principle rather than a constitutive principle).

These obstacles arise because there are no specific implementing regulations regarding copyright as an object of fiduciary guarantee. This situation creates a large enough risk for banks to accept copyright as collateral. The copyright is an intangible movable object which until now there is no standard regulation on how to judge or estimate the economic value of a copyright.

Article 6 Law Number 42 of 1999 concerning Fiduciary Security stipulates that the Fiduciary Security deed made by a Notary Public must include the guarantee value and the value of the objects used as the object of the fiduciary guarantee; it raises a new question, where is the value obtained? How can the calculation of fiduciary guarantee object to copyright be applied in Indonesia?

\subsection{Economic Rights in Copyright as Fiduciary Guarantee}

As a guarantee for payment or repayment of certain debts, the debtor is required to provide collateral (valuable), high quality, at least the same (equal) to the amount of the debt. For this reason, banks and other financial institutions or even individuals should ask for collateral material with the intention that if the debtor is unable to pay off his debt or is declared bankrupt, the collateral material can be cashed to cover repayment or refund of the remaining money.

In relation to Intellectual Property as collateral (guarantee), in simple guarantee law, it can be interpreted as a law that regulates debt security, both in the form of material and individual guarantees.[10] The individual guarantee is an agreement between a creditor and a third person that ensures the fulfilment of the debtor's obligations. That agreement can be made without the permission of the debtor. Material guarantees can be made between the creditor and the debtor, or between the creditor and a third person that guarantees the fulfilment of the debtor's obligations.

Intellectual Property as a Fiduciary Guarantee, in the process, an appraisal will be carried out (appraisal, valuation), especially from the lender in determining the economic value of collateral, because copyright is an intangible asset, In accounting, it is referred to as an intangible asset, where intangible assets are non-monetary assets that have no physical form on the company's balance sheet, which is used to produce goods and services.[11]

Guarantee, in general, is always associated with the provision of credit or financing. M. Syafi'I Antonio explained that financing is one of the main duties of a bank, namely providing funding facilities to meet the needs of parties who are deficit units.[12] According to the Banking Law, Number 10 of 1998 is the provision of money or equivalent claims, based on an agreement or agreement between the bank and another party which requires the financed party to return the money or claim after a certain period in exchange or profit-sharing.[13] A financial institution even though it is not a bank, including a financing institution, in providing credit or financing generally asks for guarantees from the debtor. The guarantee mentioned here was a material guarantee or an individual guarantee.

The fiduciary guarantee is a special guarantee that arises because of a special agreement between 
the debtor and creditor and can be executed without going through a court decision because the head of the Fiduciary Security Deed has written the title of executorial in the form of irah-irah, namely the sentence "For Justice Based on the Lordship. Almighty". In Indonesia, fiduciary security is regulated by Law Number 42 of 1999 concerning Fiduciary Security (UUJF). Fiduciary guarantee agreement; the nature of the accessoir as stated in Article 4 of the UUJF which reads "Fiduciary guarantee is a follow-up agreement of a principal agreement, not an obligation for the parties to fulfil the achievements.".[14] The consequence of the following nature of fiduciary is that the fiduciary guarantee is nullified by law when the debt guaranteed by the fiduciary guarantee is written off.[15]

In fiduciary, the collateral object is not controlled by the creditor and remains under the control of the debtor, and is not accompanied by physical delivery. A fiduciary agreement is made in writing in the form of a notary deed and registration is also mandatory at the Fiduciary Registration Office. After the new registration will be born a fiduciary guarantee. Thus, if a copyright is to be used as a fiduciary guarantee, the work must first be registered at the Directorate General of Intellectual Property. In order to be clear in case of default, the giver of a fiduciary is the copyright holder and the execution can be carried out without having to go through a court decision

The appraisal mechanism for objects that will be used as collateral and burdened by the guarantee institution, a practice that has been carried out by creditors (creditors) financial institutions, uses a public appraisal service called appraisal. Public Appraiser is a third party who is a supporting profession in the financial sector and can provide professional judgment regarding the assessment of the economic value of objects, which will then be burdened with the guarantee institution. This Public Appraiser Profession is regulated by Regulation of the Minister of Finance of the Republic of Indonesia Number 101 / PMK.01 / 2014 concerning Public Appraisers. In this regulation, Appraiser is someone who has competence in carrying out Appraisal activities, who at least has passed the initial assessment education, and Public Appraiser is an Appraiser who has obtained permission from the Minister to provide services as regulated in that Ministerial Regulation. The authority of the Public Appraiser includes the following Appraisal services:

1) Simple Property Appraisal;

2) Property Valuation; and

3) Business Valuation.
Assessment of a Copyright is included in the Business Appraisal service sector which includes:

1) business entity;

2) inclusion;

3) securities including derivatives;

4) company rights and obligations;

5) intangible assets;

6) economic losses caused by certain activities or events to support various corporate actions or material transactions;

7) fairness opinion; and

8) financial instruments.

In conducting the assessment, Public Appraisers use the Indonesian Assessment Standards, hereinafter abbreviated as SPI. SPI is a basic guideline that must be adhered to by the Appraiser in conducting the Assessment. The procedures and assessment mechanisms implemented by Public Appraisers in accordance with Article 4 of the Regulation of the Minister of Finance of the Republic of Indonesia Number 101 / PMK.01 / 2014 concerning Public Appraisers are as follows:

1) identifying and understanding the scope of the engagement;

2) collecting, selecting, and analyzing data;

3) applying the Appraisal approach; and

4) compiling an Assessment Report.

In the asset appraisal stage by the Public Appraiser, retrieved from the official website of one of the Public Appraiser's offices is as follows:[16]

1) Preparation

2) Field survey (asset documentation, data search)

3) Analysis, using the method:

a) The market data approach or often referred to as the sales comparison method or the direct market comparison method is a method of valuation carried out by directly comparing the valued property with similar property data;

b) In the cost approach, using the cost calculation method, the property value (land and buildings) is obtained by considering the land as vacant land, the land value calculated using the market data comparison method (market data approach). Meanwhile, the building value is assessed using the cost calculation method; and

c) The income approach, where the value of the property depends on the property's ability to generate profits.

4) Recap of results

5) Making the final report

Currently, to determine the value of objects in the form of land and buildings, Public Appraisers use a 
fair market value following the value in the area. Market Value is defined as the estimated amount of money that can be obtained at the valuation date. For collateral of intangible objects are credit, then the value of the object is the same as the amount of the credit. Then these values will be included in the appraisal report for consideration by financial institutions to provide loans. According to provision 15 / PBI / 2012 concerning Assessment of Asset Quality for Commercial Banks Article 43, collateral that can be calculated is stipulated as follows:

1) Securities and shares that actively traded on a stock exchange in Indonesia or have investment-grade and bound under pledge;

2) land, buildings, and houses bound by mortgage rights;

3) machinery which is an integral part of the landbounded with mortgage rights;

4) aircraft or ships with a size of more than 20 (twenty) cubic meters bound by a mortgage;

5) motor vehicles and supplies bound fiduciary; and/or

6) warehouse receipts bound with guarantee rights on warehouse receipts.

Until now, the Intellectual Property certificate is not included in the collateral list mentioned by the authority of Bank Indonesia. Copyright, no assessment guideline can be used by Public Appraisers, so it cannot become collateral at financial institutions. The government also has not regulated (regulations) regarding the mechanism of fiduciary imposition on copyright. We can learn from the United States in Copyright Law of the United States and Related Laws Contained in Týtle 17 of the United States Code, has stipulated that one of the transfers of copyright is through a guarantee or commonly called a Mortgage, as contained in the provisions of Definitions, Subject Matter and Scope of Copyright :

"A "transfer of copyright ownership" is an assignment, mortgage, exclusive license, or any other conveyance, alienation, or hypothecation of a copyright or of any of the exclusive rights comprised in a copyright, whether or not it is limited in time or place of effect, but not including a nonexclusive license." (Copyright Law of the United States and Related Laws Contained in Týtle 17 of the United States Code)

In America, there is a certain institution, namely Royalty Judges, which has the authority to determine the value of royalty fees. It regulates all matters related to royalties, the rights and obligations of parties related to copyright using, as well as sanctions for parties who do not pay these obligations.

In Indonesia, similar institutions are regulated by the Copyright Law, namely the Collective Management Institution (LMK). A non-profit legal entity authorized by the Author, Copyright Holder, and/or Related Rights owner to manage their economic rights in the form of collect and distribute royalties. It can assist the efforts of Public Appraisers in assessing copyright, by providing official data of the number of royalties received by copyright holders for a period of time, to be used as a basis for consideration of the economic value of copyright. based on the description above, there is no statutory regulation as the basis for a fiduciary charging mechanism for Copyright, there are several criteria that become a basis for assessing the economic value of a Copyright as credit collateral, including:

1) Copyright must be registered with the Directorate General of Intellectual Property Rights, Ministry of Law and Human Rights.

2) The copyright already has an estimated economic value that can be accounted for, it can be seen from the contract value with the company that uses/distributes/displays the copyrighted work.

3) The copyright has been managed by the Collective Management Institute so that the royalty value can be known.

4) Lending is given on a prudent basis, in the sense that the amount of credit value, allocation, and period must comply with the provisions of Bank Indonesia and or the Financial Services Authority.

5) Certificate of Intellectual Property Rights included in the types of collateral allowed in bank credit financing

6) If necessary, another guarantee is given in the form of a personal guarantee from the company that houses the copyrighted work (for example, a personal guarantee from the owner of the music label company that houses a songwriter).

\subsection{Method of Appraisal of Rights as Fiduciary Guarantee}

In the concept of banking guarantees in the world, as stated by Steven Emanuel and Ray D. Henson who see that collateral is said to be part of the security concept.[17] There are three forms of security, namely mortgage/hypothec: a debt instrument by granting mortgage rights over property and borrowers to the lender as collateral for their obligations; in this case, the borrower can still use or utilize the property; mortgage right on "fall property" after paying the debt, Pledge (Pawn), and 
Lien. (In the dictionary of Bank Indonesia, the equivalent of a Pledge, namely the rights of creditors to certain assets as collateral for credit). Insecurity, there are two types of property concepts that are categorized as loan collateral, namely Real Property and Personal Property. Real property is always associated with land ownership (freehold land). Whereas, personal property is associated with leasehold landholders and all movable objects as well as chattels.

Intellectual property is part of choices in action, which are properties that are physically invisible so that they cannot be protected from a physical perspective and therefore require a court order. The copyright is an intangible property such as checks, proof of patent rights, copyrights, and others. An economic assessment of copyright must meet the requirements, among others:[18]

1) A copyright work must be specifically identifiable ;

2) There must be concrete evidence or manifestation of the existence of the copyrighted work (for example, a contract, license, registration document, computer diskette, a set of procedural documentation, a customer list, recorded on a set of financial reports, etc.);

3) The copyrighted work has been created/already exists;

4) The copyrighted work must have legal protection and can be legally transferred;

5) The copyrighted work must have a sale value.

In general, there are three methods used for the assessment of guarantees. The method can also assess the intellectual property and analyze copyright. Intellectual property assessment can be compared to various valuations by banks, including

1) Market value;

2) New replacement cost (reproduction cost);

3) Fair value (depreciated replacement cost);

4) Liquidation value;

5) Insurance value (insurable value/actual cost value)[17]

According to Sri Mulyani, in the journal of legal dynamics, there are several approaches to assessing intellectual property as an object of guarantee.[8]

\section{1) Market Approach}

The market approach method provides a systematic framework for estimating the value of an intangible asset based on an analysis of actual sales and/or intangible license transactions in proportion to the object.

This method is a method by which Intellectual Property Rights or intangible assets are valued by comparing them to recent sales, transfers, and transactions involving the same assets in the same market. The problem with this market value approach method is the difficulty in analyzing the selling value of a copyrighted work. In other words, it is difficult to convert data for what the price is "per image", "per lyrics", or "per word".

Besides, a market approach to valuation has been used with tangible assets where the market has existed for decades, in areas such as real estate, equipment, and raw materials. However, intangible assets, at least to date, have not been bought and sold frequently enough to be able to build value-based solely on comparisons of direct market value; Therefore, analysis and adjustments are almost always necessary. Also, transactions in intangible assets are often in secret.

\section{2) Income Approach}

The income approach method provides a systematic framework for estimating the value of intangible assets based on the capitalization of economic income or their present. The economic value of income will come from the use, license, or rental of the intangible object.

This method determines the economic value based on future income that can or will be, generated from intellectual property or intangible assets. The income approach to intellectual property rights is a widely used valuation method; however, it can be complex, since you have to decide how to measure "income". The three basic parameters of the income approach are:[18]

a) A next revenue

b) Duration of revenue

c) Risk level or assets depreciation

There are several other methods such as the Brand Value Equation Methodology, the Competitive Advantage Technique, and the royalty approach; however, the three methods above are the most common methods used in countries that adhere to the common law system such as the United States and the United Kingdom.

\section{3) Cost approach}

The cost approach method provides a systematic framework for estimating the value of intangible assets based on the economic principle of substitution that is commensurate with the costs to be incurred as a proportionate substitute as a utility function.

In principle, this method is based on the costs incurred to develop or create a copyrighted work, or a similar product or 
service, without considering the economic value of the copyrighted work. It states that the value of an object or part of intellectual property is not greater than the cost to produce it.[18] Many variations can be included regarding the cost components, ranging from labour costs, registration fees for intellectual property protection, as well as marketing costs and "soft" costs, namely time costs.[18] The cost approach does have certain limitations in analyzing the economic value of a copyright. Because of these limitations, the cost approach is often assumed to provide only the benchmark for the lowest estimates of economic`s value.

Of the several approaches mentioned above, in practice, there is no single method that can be applied in Indonesia, because fiduciary officers will experience difficulties in estimating the economic value of goods/collateral in the form of copyright. There are no detailed regulations regarding the implementation of copyright registration which is guaranteed through fiduciary. Fiduciary institutions must begin to prepare to accept copyright as an object of debt guarantee by considering that copyright can be used as a debt guarantee object as stipulated in the Copyright Law, where the guarantee institution is fiduciary.

\section{CONCLUSION}

The results show that three approaches can be used to estimate the economic value of copyright. The first is the cost approach method, which is an assessment method based on the costs incurred in developing or creating a copyrighted work or similar product. The second method is a market approach, namely the valuation method by comparing recent sales, transfers, and transactions involving the same assets in the same market. The third income approach methods, namely the approach to determining economic value based on future income that can be generated. Indonesia can choose the market value approach method because the copyright is assessed by an analysis of the actual sales proportional to the object. The choice of the market value approach method will be successful, but the government must ensure the availability of technical implementing regulations governing the use of copyright as debt collateral, the obligation to register copyright in the public register of works, and an independent copyright assessment agency.

\section{REFERENCES}

[1] M. Sani, "Rancangan Undang-Undang Tentang Hak Cipta," Direktorat Jenderal Peraturan Perundang-undangan, 2014. [Online]. Available: http://ditjenpp.kemenkumham.go.id/64rancangan-peraturan/rancangan-undangundang/2112-rancangan-undang-undangtentang-hak-cipta.html. [Accessed: 09-Oct2020].

[2] LMKN, "Pendapatan Royalti." [Online]. Available: https://www.lmkn.id/perolehanroyalty/. [Accessed: 10-Oct-2020].

[3] D. Marhendri, "Lembaga ini Ungkap 5 Penyanyi dengan Royalti Tertinggi," merdeka.com, 2020.

[4] Liputan6.com, “KCI Bagikan Royalti Rp 5,3 Milyar Kepada Pencipta Lagu," Liputan6.com, 2019.

[5] T. Redaksi, "Menghitung Penghasilan Seorang Penulis Buku," Mojok.co, Jun2020.

[6] Admin, "Hak Kekayaan Intelektual dalam Produksi Film,” LMKN, 2019. [Online]. Available: https://www.lmkn.id/2019/09/24/hakkekayaan-intelektual-dalam-produksi-film/. [Accessed: 10-Oct-2020].

[7] I. Hariyani, "Penjaminan Hak Cipta Melalui Skema Gadai dan Fidusia," J. Huk. IUS QUIA IUSTUM, vol. 23, no. 2, pp. 294-319, 2016.

[8] S. Mulyani, "Pengembangan Hak Kekayaan Intelektual Sebagai Collateral (Agunan) Untuk Mendapatkan Kredit Perbankan Di Indonesia," J. Din. Huk., vol. 12, no. 3, pp. 568-578, 2012.

[9] N. E. Elnizar, "Hak Cipta Sebagai Jaminan Fidusia Terhambat Sistem Valuasi," Hukum Online, 2018. [Online]. Available:

https://www.hukumonline.com/berita/baca/1 t5bb340c6822c8/hak-cipta-sebagaijaminan-fidusia-terhambat-sistem-valuasi. [Accessed: 09-Oct-2020].

[10] J. A. dan M. Joni, "Pemanfaatan Sertifikat HKI Sebagai Collateral Kredit," vol. 6, p. 133, 2011.

[11] S. dan I. Y. G. Lisvery, “ASET TAK BERWUJUD .pdf," Jurnal Akuntansi dan Keuangan Indonesia, vol. 1. pp. 1-15, 2004. 
[12] M. S. I. Antonio, Bank Syariah dari Teori ke Praktik. Jakarta: Gema Insani Press, 2001.

[13] Kasmir, Manajemen Perbankan. Jakarta: PT Raja Grafindo Persada, 2002.

[14] Supianto, Hukum Jaminan Fidusia: Prinsip Publisitas pada Jaminan Fidusia. Yogyakarta: Garudhawaca, 2015.

[15] J. Satrio, Hukum Jaminan Hak Jaminan Kebendaan Fidusia. Bandung: Citra Aditya Bakti, 2000.

[16] Admin, "Tahapan Penilaian Aset," KJPP Tri, Santi \& Rekan, 2011. [Online]. Available: http://www.kjpptrisanti.com/index.php?opti on=com_content \&view=article \&id=50:peni laian-aset\&catid=31:umum-jasa-danpelayanan\&limitstart $=5$. [Accessed: 09Oct-2020].

[17] I. Rahmatullah, Aset Hak Kekayaan Intelektual Sebagai Jaminan dalam Perbankan. Yogyakarta: Deepublish Publisher, 2015.

[18] R. Budi Setianingrum, "Mekanisme Penentuan Nilai Appraisal Dan Pengikatan Hak Cipta Sebagai Objek Jaminan Fidusia," J. Media Huk., vol. 23, no. 2, pp. 229-238, 2017.

[19] D. P. Saraswati, "Mengenal Porto Mento, Sistem yang Melindungi Hak Cipta dan Royalti," detik.com, 2019. 